\title{
INFLUENCE OF BIO-POLLUTION ON ECOSYSTEM PROCESSES: THE IMPACT OF INTRODUCED LAKE TROUT on STREAMs, Predators, AND Forests in Yellowstone National PARK
}

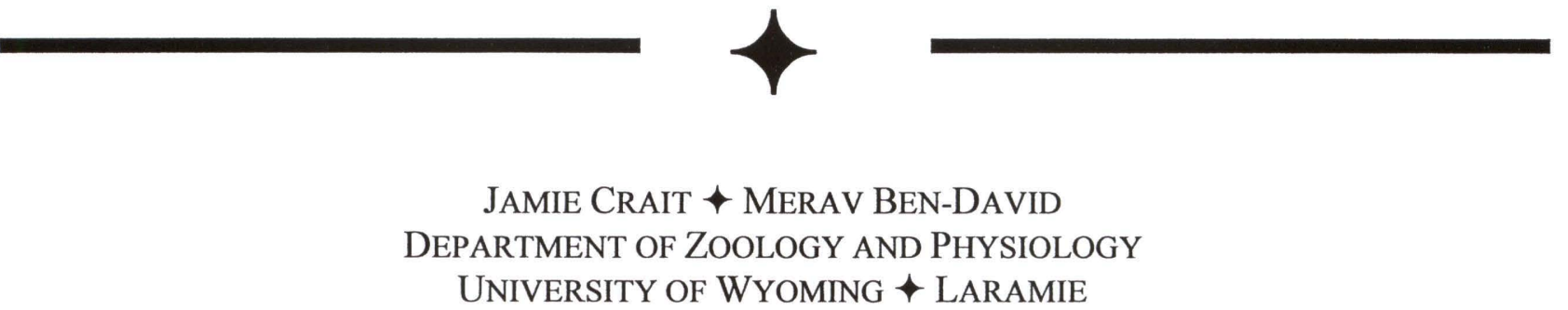

\section{$\downarrow \quad$ INTRODUCTION}

Recently an unauthorized introduction of lake trout (Salvelinus namaycush) to Yellowstone Lake was documented. Recent investigation at the University of Wyoming indicated that in-lake predation by lake trout on juvenile and sub-adult native Yellowstone cutthroat trout (Oncorhynchus clarki bouvieri) could negatively influence recruitment of cutthroat trout (Stapp and Hayward 2002). This may lead to significant reductions in numbers of spawning adult cutthroat if current management actions are ineffective or if they are not continuously pursued (Stapp and Hayward 2002). While lake trout invasion in Yellowstone Lake will likely have detrimental effects on in-lake communities and processes, a reduction in the native cutthroat trout population could potentially impact other aquatic and terrestrial ecosystems outside of Yellowstone Lake.

Cutthroat trout in Yellowstone Lake annually migrate into tributary streams and rivers to spawn (Varley and Gresswell 1988), with runs up to 60,000 trout per season into small streams such as Clear Creek (Gresswell and Varley 1988). This spawning migration may significantly affect instream communities (cf. Power 1990) and alter nutrient cycling within tributary streams (Peterson et al. 1993) and in the adjacent riparian forests (BenDavid et al. 1998; Hilderbrand et al. 1999).
Therefore, spawning cutthroat trout not only have trophic effects on their ecosystem but also act as "ecosystem engineers" (i.e., species that influence structure and function of ecosystems through nontrophic processes) because of their role in transporting large amounts of nutrients between ecosystems (Jones et al. 1994). Reductions in spawning adult cutthroat trout will likely alter instream processes. In addition, for piscivorous (fisheating) predators, a significant decline in the number of adult spawning cutthroat trout may reduce recruitment and survival, and it could threaten viability of predator populations.

In this project we are investigating the importance of cutthroat trout to a representative fishpredator - the river otter (Lontra canadensis), and possible effects on terrestrial plants through nutrient transport by otters to latrine sites (Ben-David et al. 1998; Hilderbrand et al. 1999). We hypothesized that the spawning migration of cutthroat trout will result in transport of nutrients from lake to streams, and from streams to terrestrial forests, through the activity of river otters. Documentation of such transport will enable us to predict how trout predators and the terrestrial landscape will be affected following cutthroat trout declines. Specifically, we predicted that: 1 . Spawning cutthroat trout will be seasonally a major food resource to river otters. 2 . Spawning migrations of cutthroat trout and the resulting predation by river otters will create a flux of 
nitrogen $(\mathrm{N})$ to riparian forests. 3. Tree-ring widths and stable nitrogen isotope values of tree-rings from river otter latrine sites will reflect temporal changes in cutthroat trout and otter abundance. 4. Future reductions in spawning cutthroat trout will lead to declines in number of otters.

\section{$\uparrow \quad$ METHODS}

\section{Sampling design}

Surveys for river otter signs were conducted from June 11 to August 7, 2002 and from May 23 to August 15, 2003. Areas surveyed included: Yellowstone River inlet, Yellowstone River from the outlet to the Lower Falls; Pelican, Sedge, Cub, Clear, Columbine, Bridge, and Arnica Creeks, and the perimeter of Yellowstone Lake excluding nonmotorized zones (Figure 1). This time period coincided with the beginning, peak, and end of the spawning season of cutthroat trout. Nonetheless, because our permit allowed only limited access to bear management areas (BMAs), Bridge, Arnica, Sedge, and Columbine Creeks were only surveyed at the post-spawning period. This resulted in incomplete sampling (i.e., missing of pre and peak spawning) on those streams. Heavily braided channels and marshy conditions prevented a thorough sampling of the Yellowstone River inlet area. In addition, because of temporal differences in the initiation of spawning migrations in streams, our surveys did not capture the early May spawning conditions on Cub and Clear Creeks.

Surveys were conducted from a small boat along the lake shoreline and on foot along tributary streams. A survey team included at least 3 people equipped with bear repellent, survival gear, and a handheld marine radio. Surveys conducted in BMAs were coordinated with NPS staff. Total stream length surveyed was $43.3 \mathrm{~km}$ in 2002 and $52.8 \mathrm{~km}$ in 2003 . Total length of lake shoreline surveyed was $175 \mathrm{~km}$ in 2002 and $203 \mathrm{~km}$ in 2003. River otter latrine sites were identified by trails leading from water, presence of feces, and tracks. Random sites were systematically selected at the location of the survey group every hour on the hour. This systematic sampling began at the start of each survey period. We resorted to this sampling scheme because it was impossible to a priori select sites randomly because of error associated with converting GIS points to GPS locations (i.e., pre-chosen sites would often be located away from a stream).
Figure 1. Locations of otter latrines and random site along the shore of Yellowstone Lake and tributary streams between June 11 and August 7,2002, and between May 23 and August 15, 2003.

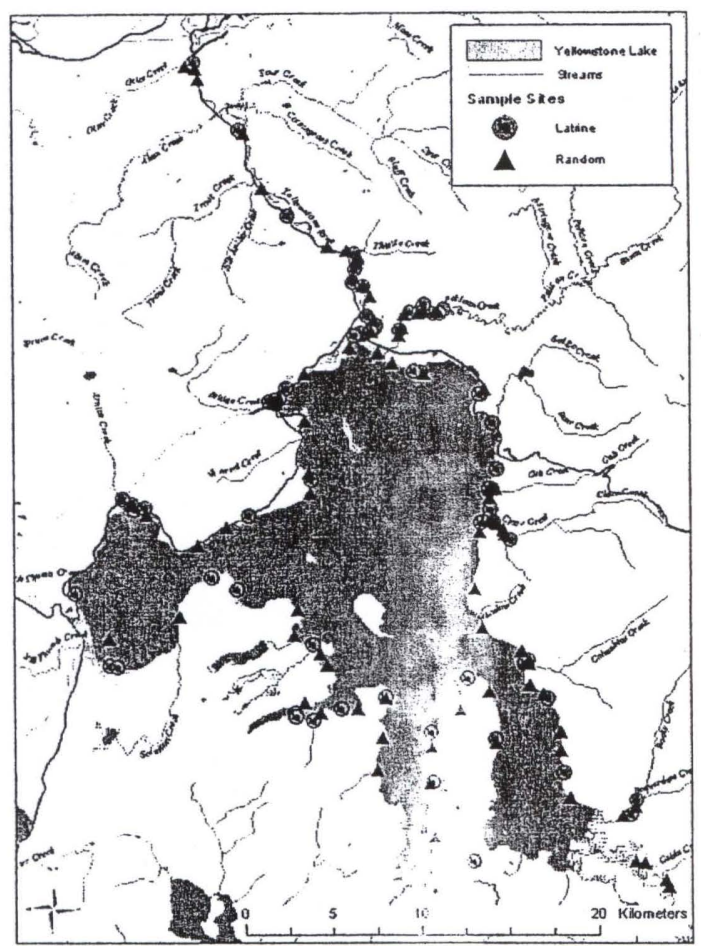

\section{Data collection}

Activity sites of otters were identified, and the location of each site was determined using a handheld GPS unit. Each site was then characterized with respect to topography, composition of terrestrial vegetation, composition of river substrate, and presence of feces. Vegetation and river substrate were assessed for a $10-\mathrm{m}$ arc with its pivotal point at the highest concentration of otter sign. We estimated relative cover of vegetation visually. Cover was estimated for both the overstory and understory. Classes for the overstory included spruce, poplar/aspen, alder, pine, and other. The understory was classified into brush, ferns and forbs, moss, and other. Vegetation types were assigned ranks of cover from 1 to $5(1=0-20 \%, 2=20-40 \%, 3=40-60 \%, 4=$ $60-80 \% 5=80-100 \%)$. We used the same method to categorize river substrates into the classes: sand, gravel, cobbles, small rocks, and large rocks. Stream shading was also estimated in the same $10-\mathrm{m}$ arc. We measured vegetated slopes to the nearest $5^{\circ}$ with a hand-held compass, and aspect of the site was recorded in eight compass directions. The distance of each site to water was measured to the nearest $0.5-\mathrm{m}$, and water temperature at the entrance to the site was measured to the nearest $0.1^{\circ} \mathrm{C}$ with a digital thermometer. At each site the number of old 
(deposited more than 24 hours before the survey), and fresh feces were recorded. Fresh feces were collected individually in $100 \%$ ethanol for DNA analysis. Random sites were characterized using identical methods.

Latrine sites were revisited between 2 and 5 times through the survey period to determine changes in activity in relation to the spawning schedule of cutthroat trout. At each visit we recorded the number of old and fresh feces, and collected fresh feces. At each site we also recorded changes in water level and temperature, and in the stream sites, counted the number of visible cutthroat trout. At two sites, Cub Creek and near Terrace Point in the SE Arm, we deployed Trailmaster ${ }^{\circledR}$ remote camera systems.

At each latrine and random site, we collected samples of vegetation for stable isotope analysis. New growth was collected from Engelmann spruce (Picea engelmannii), subalpine fir (Abies lasiocarpa), lodgepole pine (Pinus contorta), alder (Alnus sp.), currant (Ribes sp.), Vaccinium sp., willow (Salix sp.), sagebrush (Artemisia sp.), and grass (Table 1). We obtained digital pictures of each site as a means to identify individual plants for repeated samples. Small rock-cairns were placed to assist in relocation of sites.

Table 1. Vegetation samples collected at river otter latrine sites and random sites on Yellowstone Lake and tributaries, summer 2002 and 2003. Samples from 2003 are currently being prepared for stable isotope analysis.

\begin{tabular}{|c|c|c|c|}
\hline Species & Scientific name & $\begin{array}{l}\text { Number } \\
\text { collected at } \\
\text { latrines }\end{array}$ & $\begin{array}{c}\text { Number } \\
\text { collected at } \\
\text { random sites }\end{array}$ \\
\hline Alder & Alnus sp. & 14 & 12 \\
\hline Aspen & $\begin{array}{l}\text { Populus } \\
\text { tremuloides }\end{array}$ & 4 & 2 \\
\hline Currant & Ribes sp. & 44 & 26 \\
\hline Douglas-fir & $\begin{array}{l}\text { Pseudotsuga } \\
\text { menziesii }\end{array}$ & 4 & 1 \\
\hline $\begin{array}{l}\text { Engelmann } \\
\text { spruce }\end{array}$ & Picea engelmannii & 66 & 48 \\
\hline Grass & & 102 & 88 \\
\hline Lodgepole pine & Pinus contorta & 52 & 66 \\
\hline Sagebrush & Artemisia sp. & 8 & 44 \\
\hline Subalpine fir & Abies lasiocarpa & 12 & 6 \\
\hline Vaccinium & Vaccinium sp. & 26 & 16 \\
\hline Willow & Salix sp. & 4 & 4 \\
\hline
\end{tabular}

We identified all plants and measured new growth for currants on latrine and random sites. In addition, on 8 random sites and 10 latrine sites, increment cores of lodgepole pine were obtained. On 10 random and 15 latrine sites increment cores of Engelmann spruce were collected. Tree cores were sanded and individual ring widths were measured to the nearest $0.001 \mathrm{~mm}$. Cross-dating of cores was performed with program COFECHA (Holmes 1983) and ring widths were standardized into a five-year smoothing curve with program ARSTAN (Cook 1985). Vegetation and core samples are currently being analyzed for values of $\delta^{15} \mathrm{~N}$.

\section{GIS analysis}

Locations of otter activity sites were plotted on a digital map of Yellowstone Lake obtained from the Wyoming Geographical Information Science Center (WYGISC). ArcView 3.2 was used to map latrine and random sites (Figure 1). Length of stream and lakeshore surveyed were calculated by measuring distances between all sample locations, using ArcView.

\section{Statistical analysis}

We employed step-wise logistic regression (SPSS for Windows 11.5, Hosmer and Lemeshow 1989) to develop a model that could be used to describe habitat selection by otters. We controlled for multicollinearity by eliminating one of any pair of variables with $\underline{r}>|0.3|$. We ensured that the data did not depart from a logistic regression model with a Hosmer-Lemeshow goodness-of-fit test. The best model was selected based on AIC scores, model goodness-of-fit, and significant contributions of variables. To determine selection for (use > availability) or against (use $<$ availability) habitat variables, we tested those variables that entered the model using contingency tables (Pearson's $\chi^{2}$ test) for the categorical variables and Mann-Whitney tests for continuous variables (Hosmer and Lemeshow 1989).

Kruskal-Wallis and Mann-Whitney tests (Zar 1999) were employed to test for differences in average fecal deposition rate for the three survey periods of early, middle, and late summer on Yellowstone Lake and tributary streams. We used ttests to test for significant difference in levels of $\delta^{15} \mathrm{~N}$ and percent nitrogen for plant tissues on latrines and random sites. Additionally, we employed linear regression to explore relationships between fecal deposition rate at latrine sites and levels of $\delta^{15} \mathrm{~N}$ and percent nitrogen in plants.

\section{RESULTS AND DISCUSSION}

\section{Otter activity and distribution of latrine sites}

During the 2002 and 2003 surveys we found a total of 87 river otter latrine sites along streams and lakeshore and characterized 102 random sites (Figure 1). A total of 206 fresh feces were collected for DNA analysis and 989 old feces for diet analysis. In 2002 , density of latrines along streams was 0.35 sites $/ \mathrm{km}$ of waterway, and $0.13 \mathrm{sites} / \mathrm{km}$ along the lakeshore. For the 2003 survey, latrine site density was $0.68 \mathrm{sites} / \mathrm{km}$ on steams and $0.15 \mathrm{sites} / \mathrm{km}$ on the lake 
(Figure 2). In addition, the average number of feces per site on streams was 4.78 in 2002 and 7.29 in 2003. Fecal deposition rate on Yellowstone Lake was $8.13 \mathrm{feces} / \mathrm{site}$ and $6.86 \mathrm{feces} / \mathrm{site}$ in 2002 and 2003 respectively (Figure 3 ). The density of latrines we found for both streams and lake was relatively low. In comparison, similar surveys conducted in Rocky Mountain National Park (RMNP) and through the Seedskadee National Wildlife Refuge (SNWR) and Browns Park National Wildlife Refuge (BPNWR) in summer 2002 recorded densities of 2.3 sites/km stream (RMNP; Herreman and Ben-David, 2002) and 1.2 activity sites/km (SNWR; Boyd and Ben-David, 2002; BPNWR; DePue 2002). In contrast, the number of feces per site we recorded was similar to that reported in those surveys, with an average of 6.1 feces per site in RMNP and 16.05 feces per site in SNWR (Boyd and Ben-David, 2002; Herreman and Ben-David, 2002). These comparisons suggest that while activity levels of river otters in Yellowstone Lake and tributaries are similar to other systems in the intermountain west, the actual abundance of otters in our study may be lower.

Because otter densities appeared lower than expected we conducted interviews with several Park employees and volunteers as well as with W. Wengeler (UC Davis) and R. Landis (filmmaker of "Yellowstone Otters"). Almost every person we interviewed said they had noticed a real decline in otter sightings in the last few years. Although these interviews were not conducted under rigorous scientific protocols, they provided support to our conclusion that otter numbers around Yellowstone Lake have declined in recent years.

Figure 2. Latrine site densities from 3 different spring and summer river otter surveys in the Rocky Mountain region. Only 2002 data are available for the Colorado and Green rivers.

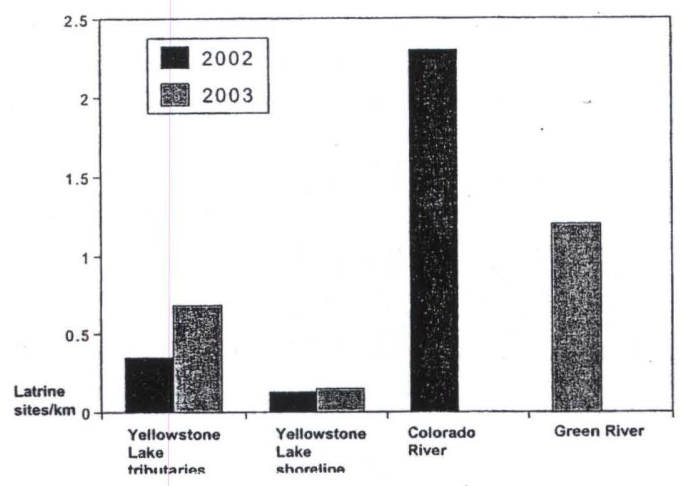

Seasonal changes in otter activity

Fecal deposition rate at otter latrine sites did seem to vary with cutthroat trout spawning activity, indicating changes in otter activity in relation to prey movement. There was a general trend towards increased otter use of spawning streams and decreased use of Yellowstone Lake during the height of spawning season, with a return to elevated otter activity on the lake after spawning had ended. However, for Yellowstone Lake, late summer 2003 was the only statistically significantly different period of otter activity (Figure 4). The 2002 results (Figure 4) should be viewed with caution because we did not have a boat available to survey the lake until mid-July. No single tributary stream had statistically significant differences in otter activity for the three study periods. When data for all streams were combined, fecal deposition rate in late summer was significantly lower than for the early and middle survey periods, both in 2002 and 2003 (MannWhitney; $P<0.05)$. This further suggests that otters seasonally switch their activity back to Yellowstone Lake in response to decreased availability of cutthroat trout in streams. Additional NPS spawning run data for our study years will allow us to further examine this relationship.

Figure 3. Fecal deposition rate from 3 different spring and summer river otter surveys in the Rocky Mountain region. Only 2002 data are available for the Colorado and Green rivers.

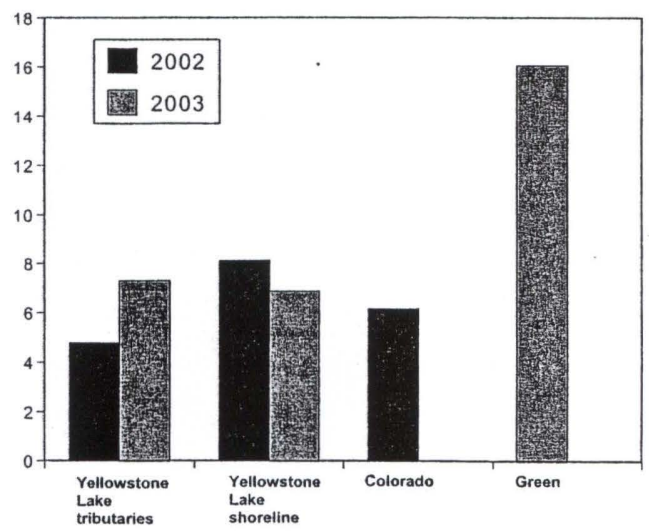

Figure 4. Fecal deposition rate at latrine sites on Yellowstone Lake, summer 2002 and 2003. The widths of the bars correspond to dates encompassed in the three different survey periods of early, middle, and late summer.

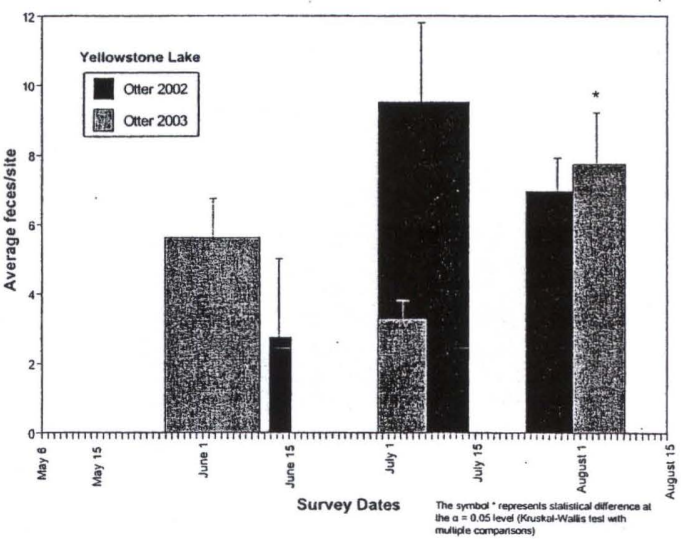


Our attempt at installing Trailmaster $^{(}$ remote camera systems to monitor otter activity at latrines met with limited success. In 2003, we were able to capture use of a latrine site on Cub Creek by two male otters. These otters showed a height of activity from June 11 to June 14 and again visited the site on June 27. The camera placed in the SE Arm failed to capture otter activity even though there was evidence that otters had been there while the camera was running. Similar problems with the camera system occurred on Cub Creek. Other authors have reported difficulties with Trailmaster $^{(}$camera systems (Rice et al. 1995). Our lack of success with these remote camera systems was likely due to a combination of camera sensitivity and low otter densities.

Although our results suggest that otters show a seasonal change in activity patterns, the importance of cutthroat trout in meeting their energetic demands awaits further investigation. While trout constitute a high-quality, energy-dense food source (Anthony et al. 2000) it is possible that otters feed heavily on alternative prey items, such as longnose suckers (Catostomus catostomus). The possibility of lake trout as a replacement food source for otters must also be evaluated. A comprehensive diet analysis of otter scats is currently being performed.

\section{Habitat selection}

For the 2002 and 2003 field seasons, the best logistic regression model identified shading, lack of understory, sand substrate, and large rock substrate as the variables most significant in discriminating latrine and random sites on streams (Table 2). This model correctly identified $77.4 \%$ of all locations to their correct affiliation. Otters selected for high presence of shade and large rocks with shallower, accessible stream banks. These results agree with those of other studies, which found high reliance of otters on old-growth forests and large rocks as aquatic substrate (Ben-David et al. 1996; Bowyer et al. 1995; 2003; Herreman and Ben-David 2001).

Table 2. Logistic regression and model used to predict occurrence of river otter latrine sites on tributaries of Yellowstone Lake, summer 2002 and 2003.

\begin{tabular}{lccc}
\hline Variable & Coefficient & SE & Significance \\
\hline Shading & 0.017 & 0.008 & 0.027 \\
Other Understory & -0.508 & 0.209 & 0.015 \\
Forbs & -0.641 & 0.219 & 0.003 \\
Brush & -0.430 & 0.214 & 0.045 \\
Sand Substrate & 0.466 & 0.151 & 0.002 \\
Large Rock & 0.391 & 0.249 & 0.117 \\
Substrate & & & \\
\hline
\end{tabular}

For lake sites the best model identified spruce overstory, alder, grasses, and presence of lagoons, tributary streams, and large rocks as the variables best separating latrine and random sites (Table 3). This model correctly identified $86.7 \%$ of all locations to their correct affiliation. Random sites were characterized by higher presence of forbs and other vegetation, and latrines were characterized by higher amounts of shading (Table 3 ). These results may indicate that river otters select for sites with higher overall vegetative cover that produces extensive shading.

Table 3. Logistic regression model used to predict occurrence of river otter latrine sites on Yellowstone Lake, summer 2002 and 2003.

\begin{tabular}{lccc}
\hline Variable & Coefficient & SE & Significance \\
\hline $\begin{array}{l}\text { Spruce } \\
\text { Overstory }\end{array}$ & 0.516 & 0.233 & 0.027 \\
Alder & 0.891 & 0.368 & 0.016 \\
Grasses & 0.623 & 0.224 & 0.005 \\
Rock & 3.815 & 1.116 & 0.001 \\
Formation & & & \\
Lagoon & 5.316 & 1.485 & 0.000 \\
Tributary & 3.513 & 1.677 & 0.036 \\
Stream & & & \\
Gravel & -0.440 & 0.230 & 0.056 \\
Substrate & & & \\
\hline
\end{tabular}

In many systems beaver (Castor canadensis) ponds and structures provide good otter habitat (Melquist and Hornocker 1983; Reid et al. 1994). This was also the case in our study; however, beaver occurrence was so infrequent that few otter latrine sites were associated with this factor. An exception was the Yellowstone River inlet area. Beaver activity in this region appeared high. While our survey here was limited in breadth, the combination of beaver activity, remoteness, spawning cutthroat trout, and key habitat structures suggests that the Yellowstone River inlet area may provide excellent river otter habitat. Additionally, distribution data from NPS gill net surveys indicate that lake trout activity is low in the SE Arm, making this part of Yellowstone Lake a possible refugium for cutthroat trout (Koel et al. 2003). If this is indeed the case, the inlet area may also provide a refugium for otters in a time of depleted prey resources elsewhere in the system. For this reason, it will be important to conduct a comprehensive river otter survey of the Yellowstone River inlet region in the future.

\section{Nitrogen transport}

For 2002, tissues in six of eight plant species were significantly enriched in $\delta^{15} \mathrm{~N}$ (one-tailed t-test; $P<0.05)$ on latrine sites compared to random sites (Figure 5). As expected, alder did not differ isotopically between latrines and random sites, as this 
species is an atmospheric $\mathrm{N}$-fixer and rarely uses soil N. Lack of significant difference in $\delta^{15} \mathrm{~N}$ for Vaccinium species was only marginal $(P=0.07)$ and may have been due to small sample size. Percent $\mathrm{N}$ in plant tissue from otter latrines was also significantly higher (one-tailed t-test; $P<0.05$ ) for all plants except sage (Figure 6). This was the case even for the $\mathrm{N}$-fixing alder. A significant positive relation also exists for fecal deposition rate and values of $\delta^{15} \mathrm{~N}$ for some plant species on otter latrines (Figure 7). This suggests that otter scent marking is at least partly responsible for differences in $\delta^{15} \mathrm{~N}$ of vegetation samples, although several other factors could be involved given that otter deposition rate explained only $23 \%$ of the variation.

Figure 5. Values of $\delta^{15} \mathrm{~N}$ (mean $\pm \mathrm{SE}$ ) of plants collected on latrine and random sites in Yellowstone National Park, summer 2002. The symbol * represents significant difference at the $\alpha$ level 0.05 .

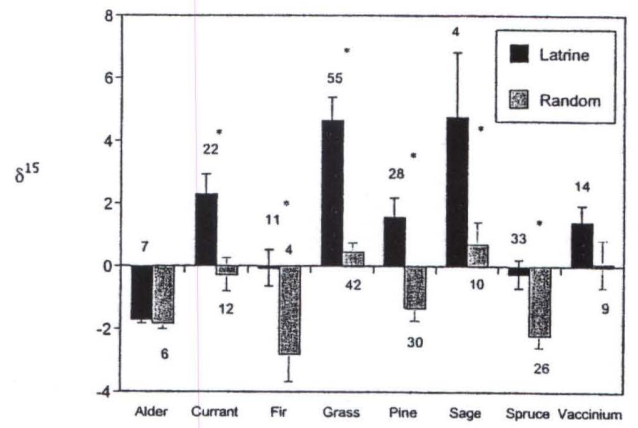

Figure 6. Values of percent $\mathrm{N}$ (mean $\pm \mathrm{SE}$ ) of plants collected on latrine and random sites in Yellowstone National Park, summer 2002. The symbol * represents significant difference at the $\alpha$ level 0.05 .

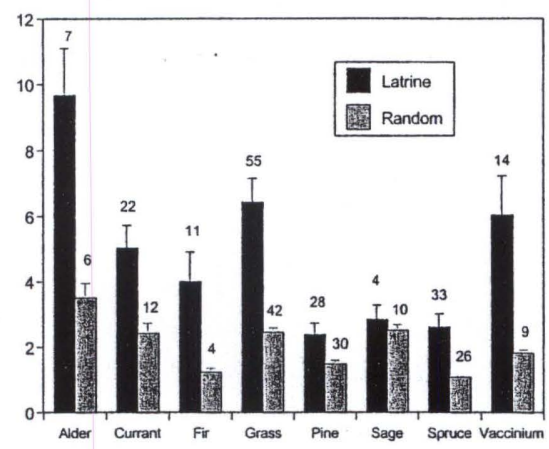

Figure 7. Linear regression for the relationship between fecal deposition rate and values of $\delta^{15} \mathrm{~N}$ for spruce needles collected in Yellowstone National Park, summer 2002.

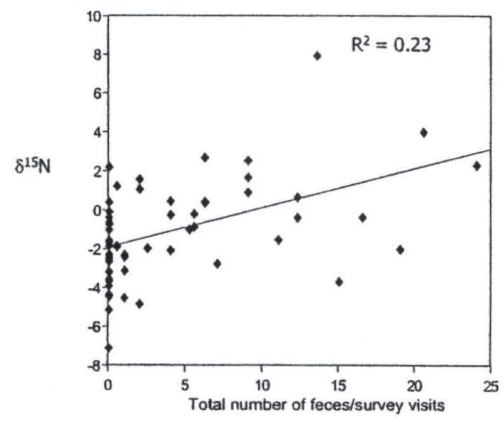

Our results support the hypothesis that river otters transport aquatically-derived $\mathrm{N}$ onto latrine sites, and in turn, fertilize some plants at these locations. These findings are similar to studies in Pacific Northwest (Ben-David et al. 1998) but, to our knowledge, are the first reported examples of otter nutrient transport and plant fertilization in the Rocky Mountain region. How and to what extent otter fertilization affects plants awaits further investigation of growth rates and differences in plant community composition. These analyses are currently underway. The $\delta^{15} \mathrm{~N}$ analyses for the 2003 plant samples will be performed when funding becomes available.

\section{Tree-ring analyses}

Preliminary results suggest that tree-ring widths alone are not a reliable proxy for temporal changes in cutthroat trout abundance and otter activity. Yearly changes in ring width on some heavily used latrine sites, especially those on the Yellowstone River, do show a correlation with changes in cutthroat trout populations (Figure 8), but this is not consistent throughout the study area. When all sites are compared, ring widths for Engelmann spruce trees from latrine sites were similar to those of random sites (Figure 9) and seemed largely driven by climate fluctuations. Small sample size and high variability of lodgepole pine precluded their inclusion in the analysis. We are analyzing tree cores for $\delta^{15} \mathrm{~N}$ in order to relate temporal changes in nitrogen isotope values to historical cutthroat populations. Other studies have shown some potential for tree ring isotope analysis as a retrospective technique for examining temporal changes in the absence of historical data (cf. Hart and Classen 2003). 
Figure 8. (A) Width of tree rings for a spruce tree growing on a river otter latrine and on a random site on the Yellowstone River. Ring widths from latrine tree track closely with changes in cutthroat abundance (B). In contrast, the random tree exhibits the typical exponential decay in ring widths. (Figure 8 (B) from Koel et al. 2003)
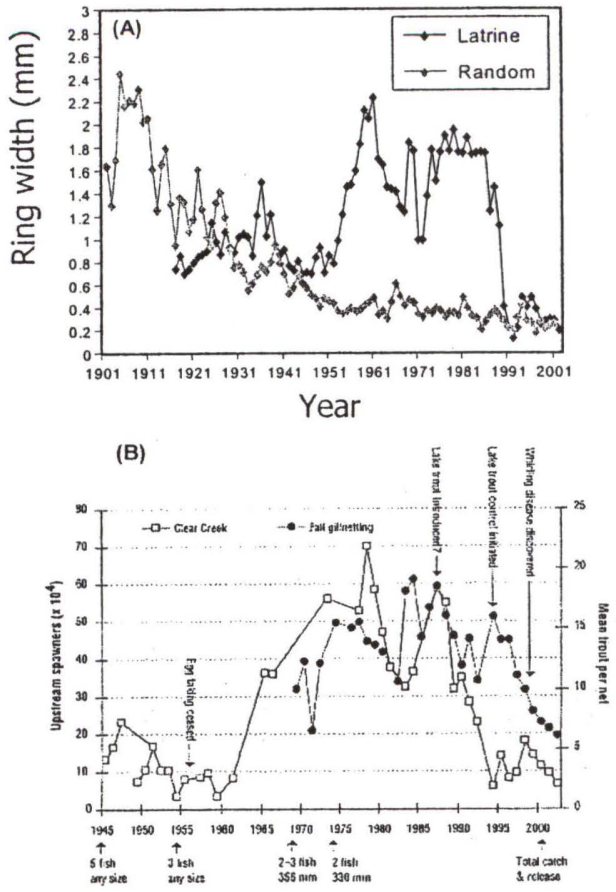

Figure 9. Standardized rings widths, on a 5-yr smoothing curve, for Engelmann spruce trees on latrine and random sites. Trees are from both Yellowstone Lake and tributary streams.

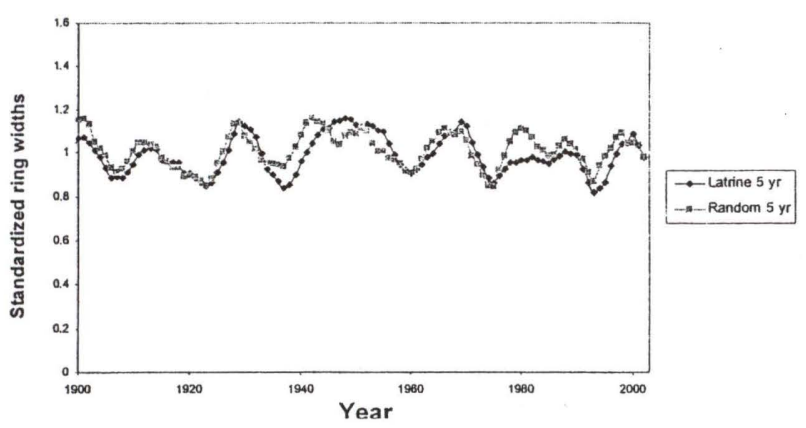

\section{$+\quad$ CONCLUSIONS}

Our results indicate that habitat selection and levels of activity of river otters in Yellowstone Lake and tributaries are similar to those of otters elsewhere, but numbers may be lower than we initially expected. Whether these lower numbers are related to the decline of cutthroat trout is yet to be established. Alternative hypotheses include:
1. Reduction in otter numbers in recent years may be caused by increased concentrations of mercury in stream waters because of reduced water flow, and

2. Exposure to canine distemper virus from an epidemic in coyotes in the late 1990s caused increased mortality in otters.

Two other major gaps in our knowledge exist: 1 . The actual number of otters in our study area awaits determination. 2. We could not evaluate whether the low numbers around Yellowstone Lake were a result of decreased population size or increased movements of otters into adjacent areas such as the Yellowstone River inlet. We expect to gain more insight regarding these issues using a suite of tools comprised of a bioenergetics model, fecal DNA analyses, stable isotope comparisons of tree-ring analyses, a survey of the Yellowstone River inlet, and a winter survey that we would like to conduct in March with the cooperation of Park biologists.

\section{ACKNOWLEDGEMENTS}

We wish to thank J. Boyd, R. Eddy, K. Ott, and $\mathrm{S}$. Schaefer for assistance in data collection in the field. B. Ertel, T. Koel, D. Mahony, E. Reinertson, and T. Wyman were helpful in coordinating surveys in bear management areas and provided boat access in the early stages of the field season. We would like to thank the Fisheries staff of NPS for their enthusiastic support and the Lake rangers for monitoring our safety. C. Hendrix was helpful and efficient in providing the research permit. W. Wengeler and $\mathrm{R}$. Landis provided valuable advice and N. P. Nibbelink kindly assisted with GIS analysis.

\section{$\downarrow$ Literature Cited}

Anthony, J. A., D. D. Roby, and K. R. Turco. 2000. Lipid content and energy density of forage fishes from the northern Gulf of Alaska. Journal of Experimental Marine Biology and Ecology 248: 53-78.

Ben-David, M., R. T. Bowyer, L. K. Duffy, D. D. Roby, and D. M. Schell. 1998. Social behavior and ecosystem processes: river otter latrines and nutrient dynamics of terrestrial vegetation. Ecology 79: 25672571. 
Ben-David, M., R. T.Bowyer, and J. B. Faro. 1996. Niche separation by mink (Mustela vison) and river-otters (Lutra canadensis): coexistence in a marine environment. Oikos 75: 41 - 48 .

Boyd J. and M. Ben-David. 2002. Survey of river otters in the Green River. Progress report. U. S. Fish and Wildlife Service, Seedskadee National Wildlife Refuge.

Bowyer, R. T., W. J. Testa, and J. B. Faro. 1995. Habitat selection and home ranges of river otters in a marine environment: effect of the Exxon Valdez oil spill. - J. Mammal. 76: 1 11.

Bowyer, R. T., G. M. Blundell, M. Ben-David, S. C. Jewett, T. A. Dean, and L. K. Duffy. 2003. Effects of the Exxon Valdez oil spill on river otters: injury and recovery of a sentinel species. Wildlife Monographs 153: 1-53.

Cook, E. R. 1985. A time series approach to treering standardization. Dissertation. University of Arizona, Tucson, Arizona, USA.

DePue, J. E. 2002. River otter (Lontra canadensis) survey of the Green River, Colorado. Unpubl. Rep. Colo. Div. Wildl., Grand Junction, CO. 4pp.

Gresswell, R. E., and J. D. Varley. 1988. Effects of a century of human influence on cutthroat trout in Yellowstone Lake. Pages 45-52 in R. E. Greswell, editor. Status and management of interior stocks of cutthroat trout. American Fisheries Society. Symposium 4, Bethesda, Maryland.

Hart, S. C. and A. T. Classen. 2003. Potential for assessing long-term dynamics in soil nitrogen availability from variations in $\delta^{15} \mathrm{~N}$ of tree rings. Isotopes Environ. Health Stud. 39: $15-28$

Herreman, J. and M. Ben-David. 2001. Population survey for river otters in the Rocky Mountain National Park. Progress report. U. S. National Park Service.

Herreman, J. and M. Ben-David. 2002. Population survey for river otters in the Rocky Mountain National Park. Progress report. U. S. National Park Service.
Hilderbrand, G.V., T. A. Hanley, C. T. Robbins, and C. C. Schwartz. 1999. Role of brown bears (Ursus arctos) in the flow of marine nitrogen into terrestrial ecosystems. Oecologia 121: 546-550.

Holmes, R. 1983. Computer assisted quality control in tree-ring dating and measurement. Treering bulletin 44: 69-75.

Hosmer, D. W. and Lemeshow. S. 1989. Applied logistic regression. - John Wiley and Sons Inc. USA.

Jones, C. G., J. H. Lawton, and M. Shachak. 1994. Organisms as ecosystem engineers. Oikos 69:373-386.

Koel, T. M., J. L. Arnold, P. E. Bigelow, B. D. Ertel, and D. L. Mahony. 2003. Yellowstone Fisheries and Aquatic Sciences: Annual Report, 2002. National Park Service, Yellowstone Center for Resources, Yellowstone National Park, Wyoming, YCR-NR-2003-02.

Melquist, W. E., and M. G. Hornocker. 1983. Ecology of river otters in west central Idaho. Wildlife Monograph 83:1-60.

Nadelhoffer, K. J., M. R. Downs, B. Fry, J. D. Aber, A. H. Magill, J. M. Mellilo. 1995. The fate of $15 \mathrm{~N}$-labeled nitrate additions to a northern hardwood forest in eastern Maine, USA. Oecologia 103: 292-301.

Peterson B. J., L. A. Deegan, J. Helfrich, J.E. Hobbie, M. Hullar, B. Moller, T.E. Ford, A. Hershey, A Hiltner., G. Kipphut, M.A. Lock, D.M. Fiebig, V. McKinley, M.C. Miller, J.R. Vestal, R. Ventullo, and G. Volk. 1993. Biological responses of a tundra river to fertilization. Ecology 74: 653-672.

Power, M. E. 1990. Effects of fish on river food webs. Science 250:411-415.

Reid, D. G., T. E. Code, A. C. H. Reid, and S. M. Herrero. 1994. Spacing, movements, and habitat selection of the river otter in boreal Alberta. Canadian Journal of Zoology 72: 1314-1324.

Rice, C. G., T. E. Kucera, and R. H. Barrett. 1995. Trailmaster $^{\circledR}$ camera system. Wildlife Society Bulletin 23: 110-113. 
Stapp, P., and G. D. Hayward. 2002. Effects of an introduced piscivore on native trout: insights from a demographic model. Biological Invasions 4: 299-316.

Varley, J. D., and R. E. Gresswell. 1988. Pages 13-24 in R. E. Greswell, editor. Status and management of interior stocks of cutthroat trout. American Fisheries Society. Symposium 4, Bethesda, Maryland.

Zar, J. H. 1999. Biostatistical analysis. PrenticeHall, Upper Saddle River, N. J. 